\title{
A Perspective on the Federal Deficit Problem
}

\author{
John A. Tatom
}

\author{
"None of us really understands what's going on with all these numbers." \\ - David Stockman, \\ Allantic Monthly, \\ December 1981
}

$\mathbf{F}$ EDERAL budget deffcits of $\$ 200$ billion or more have created considerable controversy and confusion among analysts, policymakers and voters. The important problem, of course, concerns the consequences of current and projected spending, receipts and deficits Public concern about these problems began, however, with the ballooning of deficits in 1982 and 1983.

Many analysts conjecture that recent and projected large deficits have deleterious effects on the economy - raising interest rates, exchange rates, the inflation rate, crowding out private sector investment and eco nomic growth and threatening the economic recovery. Others are more sanguine, arguing instead that recent deficits have not significantly affected interest rates, exchange rates of price behavior."

The purpose of this article is to assess these contrasting views on the causes and consequences of recent and prospective deficits. Most of the controversy arises from differences in theoretical and empirical judgments about the effects of deficits on the demand for goods and services. After examining these relevant conceptual issues, recent trends in the federal budget are taken up. Then these conceptual distinctions are used to clarify the source and potential economic effects of recent and projected deficits.

John A. Tatom is a research officer at the Federal Reserve Bank of St Louis. Thomas $H$. Gregory provided research assisfance.

${ }^{1}$ An example of the latter argument is the study by the U.S. Department of the Treasury (1984). There does appear to be general agreement about the possibility that deficits can be "monetized, "that is, financed by money creation. To the extent this occurs, inflation would accelerate.
In the view of many analysts, both current deficits and future projections indicate a major break with the U.S. postwar experience. It is suggested below that this view is unwarranted when applied to recent deficits. While recent deficits have been lange compared with earlier ones, they have arisen largely from the unusual cyclical experience in the U.S, economy, not from unprecedented fiscal policy actions that raised spending and/or reduced tax receipts. Future deficits, however, may represent a major break from the current and past experience, If so, past relationships between deficits and economic performance may prove to be of little use in judging their likely effects.

\section{THE THEORY OF ACTIVE AND PASSIVE DEFICITS}

The federal budget deficit is the excess of federal government expenditures over receipts. In analyzing the sources of the deficit and its effect on the economy, it is necessary to distinguish between "active" and "passive" components of the deficit. Spending, taxes and, therefore, the actual deficit are affected by both direct policy actions and changes in the level of economic activity, prices and interest rates. The latter changes occur passively, that is, without fiscal policy actions. Active deficits, in contrast, are those that arise from legislated changes in spending ot taxes, given the other economic conditions that influence the deficit.

One attempt to deal with this difference is the measurement of the so-called high-employment budget. It involves measuring expenditures and tax 
receipts at a high-employment level of real GNP, given actual prices and interest rates. This measure is useful because it removes that part of the actual deficit that arises from passive adjustment to cyclical fluctuations in real GNP.

For example, as real income expands, tax receipts rise and spending (primarily transfer payments) declines, so that the actual deficit shrinks. This decrease tor increase when real incomes fall) reflects automatic movements that are built-in to existing tax and spending legislation. This automatic response of the deficit to economic conditions is referred to as a change in the passive deficit. In contrast, legislated increases in spending or tax reductions raise the actual deficit at any level of GNP and produce a change in the active deficit. At each point in time, the observed deficit reflects both an active component - the size of the deficit at, for example, a high-employment level of real output - and a passive component - the part due to the business cycle.

Conventional economic analysis, which forms the basis for much of the current popular discussion, focuses on the effects of a higher active deficit that arises from either a discretionary increase in federal expenditures or a cut in taxes. The conventional wisdom indicates that an increase in the active deficit causes spending on goods and services to rise. A federal purchase of goods or services directly raises total aggregate spending; increased transfer payments or tax reductions allow greater spending in the private sector. Thus, a change in the active deficit is important because it affects the level of real GNP.

At its simplest level, the conventional analysis indicates that, if the money stock is unaltered, interest rates will rise along with real GNP. At higher levels of spending and income, the demand for money will be higher. Thus, in this view, interest rates must go up to ration the avalable money stock. Of course, a rise in rates tends to choke off some of the expansion in spending and income that results from an increase in the active deficit. This latter effect is called "crowdingout" because the rise in interest rates discourages crowds out private investment and consumer purchases.

If income and spending rise as a result of an increase in the active deficit, prices are likely to rise as well. At unchanged prices, the higher level of demand for real output is unlikely to be produced. To induce suppliers to produce more output, the general level of prices will have to be bid up. A higher level of prices indluces more crowding out, since it causes a reduction in the supply of purchasing power available from a given nominal money stock relative to the demand for it. Thus, interest rates rise further and more private spending is crowded out.

In summary, a simple version of conventional theory states that a rise in the active deficit raises not only the level of output and employment, but prices and interest rates as well. Crowding-out of private investment occurs, slowing the growth rate of economic capacity.

A rise in the passive deficit, in contrast, reflects a cyclical decline in real GNP and employment. Passive deficit increases do not exert an independent effect on economic activity. ${ }^{2}$ Moreover, such deficit increases, in the simple conventionat analysis, are typically associated with a decline in interest rates and/or prices, since cyclical declines in real GNP reflect declining demand for goods and services and credit.

There are many linkages in the results above that afe open to question. Mainstream macroeconomic conclusions depend heavily on atternative hypotheses about the sensitivity of investment, consumer spending, money demand and aggregate supply to interest rate and price level fluctuations. Depending on these assumptions, considerably different conclusions about the effects of an increase in the active deficit can emerge. 3

Central to the conventional analysis is the conclum sion that an increase in the active deficit raises the demand for goods and services at unchanged prices and interest rates. Even this result is, in principle, problematic. Some analysts emphasize that the demand for goods and services is not raised by an increase in the active deficit. Federal spending, they point out, must be financed - if not in the present, then in the future. Thus, households will tend to discount the increased future tax liability that arises from an increase in the active deficit. In effect, households match the increased deficit by an equivalent increase

\footnotetext{
"Movements in the passive deficit are endogenous with respect to movements in real GNP, while active deficits are not. A rise in the passive deficit, when real GNP falls, may reduce the extent of the real GNP dectine itself and the interest rate decline as well. Those adjustments, however, are endogenous becouse they are builinin to the structure of the economy.

${ }^{3}$ For illuminating discussions of these issues, see Carlson and Spencer (1975), Cohen and Clark (1984) and Knoester (1983). The latter shows that balanced budget increases in active tiscal policy lead to larger structural unemployment, higher wages and prices. larger future deficits and lower economic growth.
} 


\section{Chart 1}

\section{Federal Government Budget as a Share of GNP}

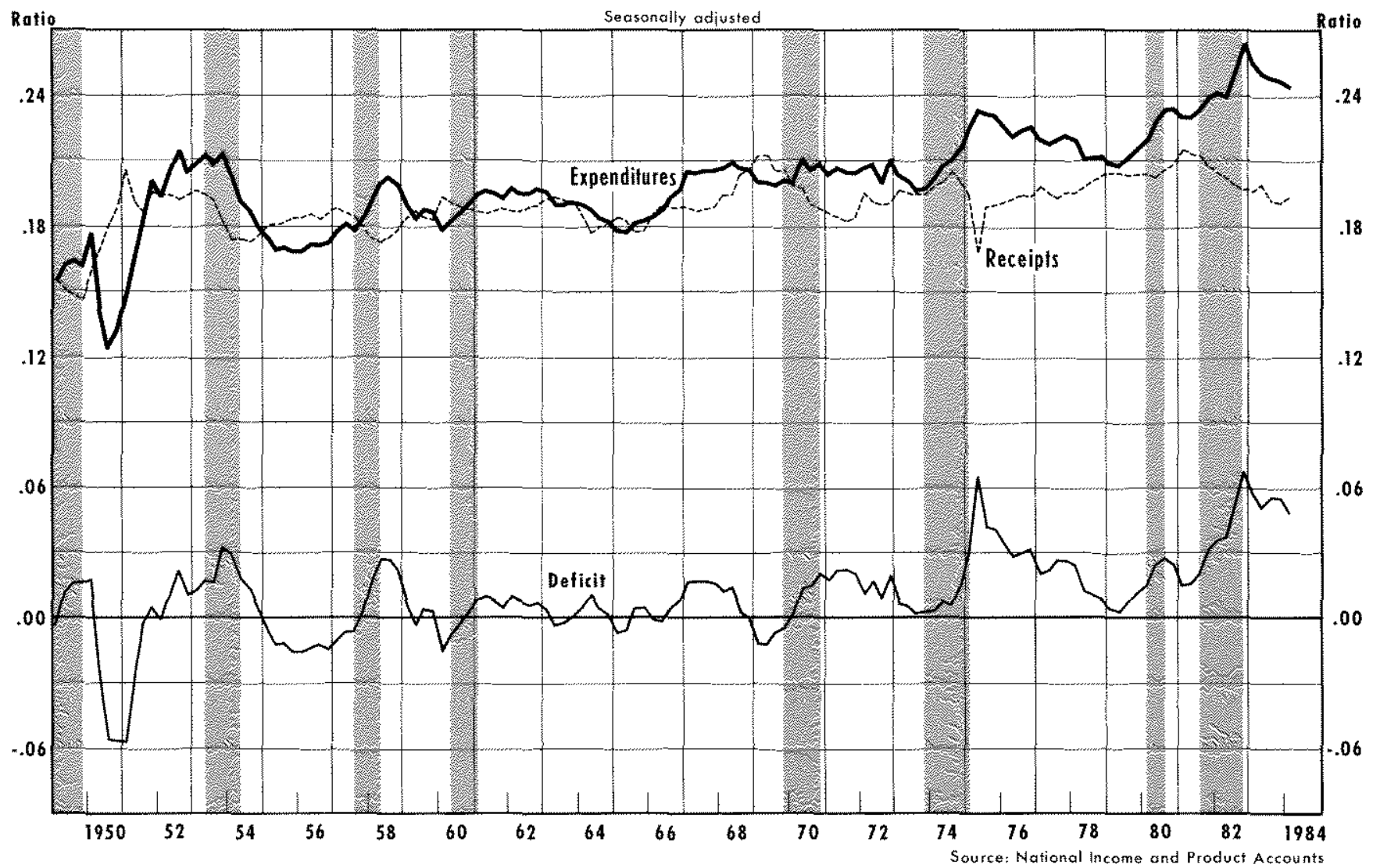

Shoded areas represent periods of business recessions.

Latest data ploted: ist quatter

in personal saving for cut in consumption!. Thus, total spending, given interest rates and prices, does not rise. ${ }^{4}$

If such discounting of future taxes occurs, the conventional conclusions about the effects of active deficits fail to hold, except for those concening crowdingout, capital formation and economic growth. Others have noted the theoretical ambiguity of mainstream theory in this regard. ${ }^{5}$ Thus, while the channels of influence of a change in the deficit are clear, especially the importance of the active-passive distinction, the assessment of the effects of a rise in the active deficit remains essentially an empirical question.

${ }^{4}$ This result is referted to as the Ricardian Equivalence Theorem. See Barro (1974, 1978), as well as Buchanan and Wagner (1977).

5 See, especialiy, the recent analysis by the U.S. Department of the Treasury.

\section{PECENT RUDGET TRENDS}

The federal budget deficit soared to $\$ 147$ billion (National Income Account, NLA, basis) in calendar yeat 1982 , then rose to about $\$ 183$ billion in 1983. Projections for the next several years range from a slight decline to a near doubling by the end of the decade. It is useful to compare the budget developments of the past two years with past trends to gain some understanding of how the deficit became so large.

Chart 1 shows the growth of federal spending and receipts as shares of GNP from 1948 to 1983 . The deficit the difference between expenditures and receipts, alsc is shown as a share of GNP. In the fourth quarter of 1982 , the deficit reached a peacetime record 6.7 percent of GNP. While this proportion subsequently de. dined, it remained above 5 percent through 1983 .

The surge in the deficit is associated with an accel eration in federal expenditure growth and a decline it 


\section{Chort 2}

\section{Federal Government Expenditures as a Share of GNP}

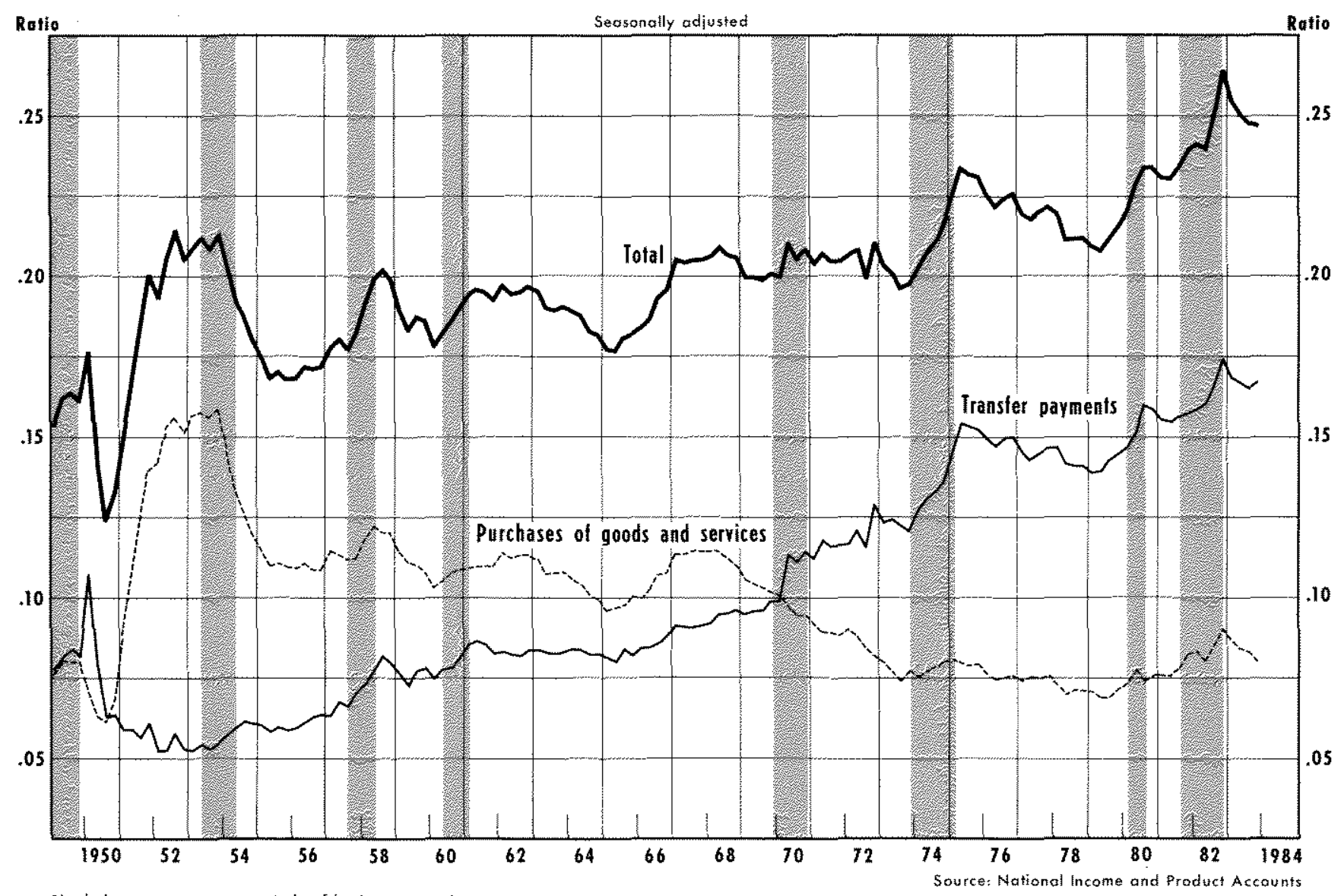

Shoded areos representperiods of business tecessions. Latest data platted: 1st quater

receipts growth, when both are measured relative to GNP. For example, from 1980 to 1983 , when GNP grew at a 79 percent annual rate, expenditures grew at an 11.1 percent rate and federal receipts rose at only a 6.0 percent rate. As a result, expenditures rose from 22.9 percent of GNP in 1980 to 25.0 percent in 1983 , and the share of receipts fell from 20.6 percent to 19.5 percent. Thus, over this time interval, the deficit widened from 2.3 percent to 5.5 percent of GNP.

\section{The Growth of Federal Expenditures}

The sharp surge upward in federal expenditures as a share of GNP is shown again in chart 2, where expenditures are broken into two majot categories: the purchase of goods and services and transfer payments including transfers to persons, state and local governments, net interest on the federal debt and subsidies to government enterprises). From 1967 to 1979, the share of expenditures in GNP rose little lexcept for a tempo- rary spurt in 1975), with the surge in transfer payments almost offset by the decline in purchases of goods and services. Since 1979, however, both components of federal expenditures have risen relative to GNP. Purchases of goods and services rose from 7.0 percent to 8.3 percent of GNP from 1979 to 1983 , while transfer payments continued their previous trend of rising faster than GNP, increasing from 14.1 percent to 16.6 per cent of GNP.

The pattern of federal purchases of goods and services closely mirrors that of national defense expendi tures (not shown), since the remainder, non-defense purchases, has remained about 2 percent to 3 percent of GNP since the earty 1960s. National defense purchases, after declining from 1968 to 1979 , rose from 4.6 percent of GNP in 1979 to 6.0 percent in 1983 . This rise accounts for all of the rise in the share of purchases in GNP, but only 36 percent of the increase in the share of expenditures in GNP and an even smaller percentage of the increase in the deficit measured relative to GND. 
Chort 3

\section{Federal Government Receipts as a Share of GNP}

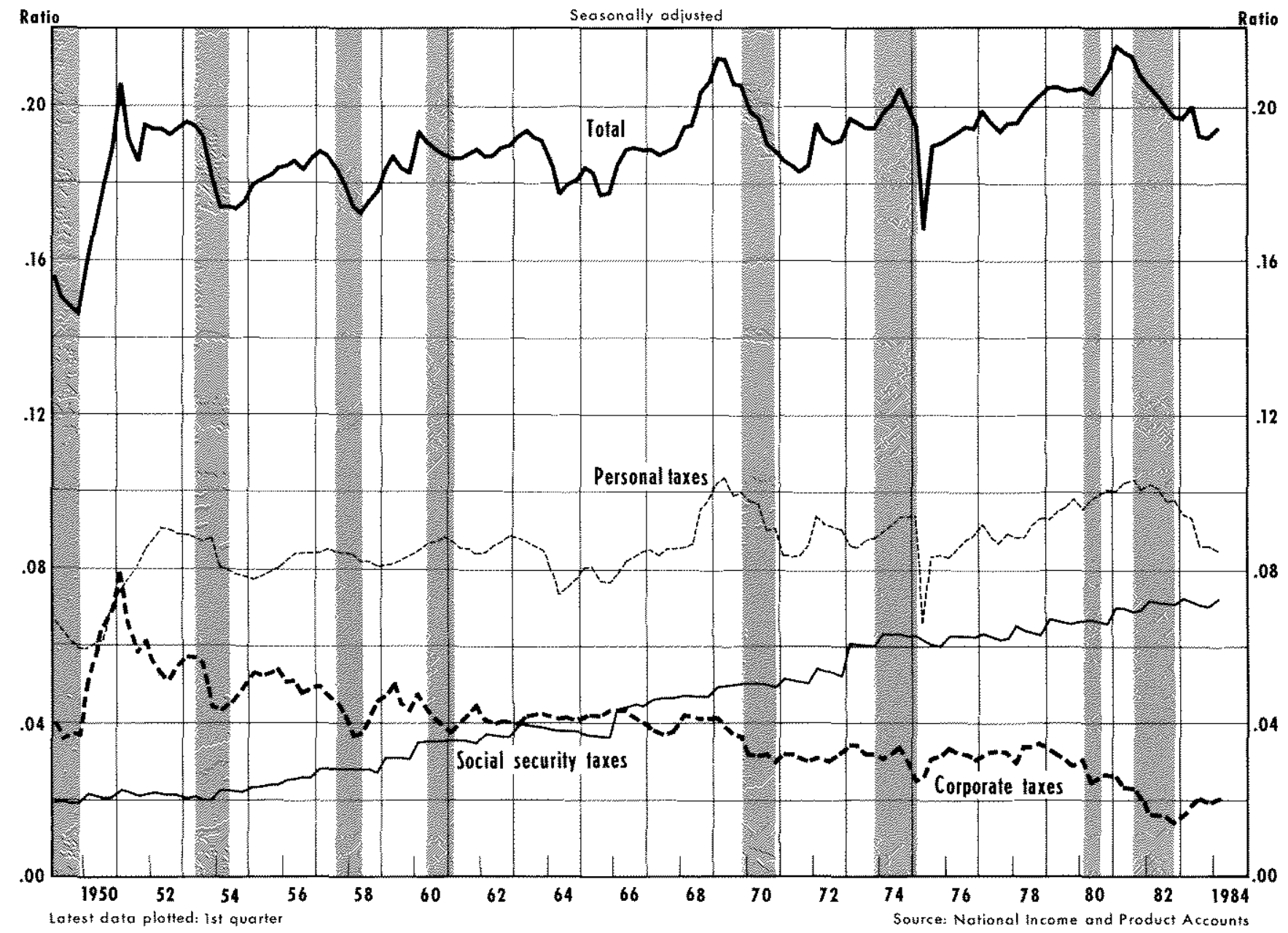

\section{Federal Receipts as a Share of GNP}

The share of federal receipts in GNP is shown in chart 3 along with its major components: personal tax and non-tax receipts, social security contributions and corporate income taxes. From 1979 to 1983, the share of social security taxes in GNP continued its upward climb, rising from 6.6 percent to 7.1 percent. This increase largely offset the decline in the share of personal taxes from 9.5 percent to 8.9 percent over the same period. Corporate taxes declined from 3.1 percent to 1.8 percent of GNP from 1979 to 1983 , a decline that reflected an actual decline in such receipts from $\$ 74.2$ billion to $\$ 59.3$ billion. In large part, this was due to a similar percentage decline in corporate profits from $\$ 252.7$ billion in 1979 to about $\$ 207.6$ billion in 1983 .

\section{The Sources of Recent Deficits}

It appears that the recent ballooning of federal deficits has been associated with a combination of adverse budgetary developments rather than a single cause. Expenditures have surged upward relative to the nation's GNP, primarily because of the continued rapid growth of transfer programs such as social security payments, Medicare, unemployment benefits and interest on the national debt. At the same time, receipts have grown more slowly than GNP, largely because of a decline in corporate income and corporate income tax receipts.

Simple explanations that attribute recent deficits to the defense buildup that began in 1979 or to tax cuts 
Chart 4

Personal Taxes as a Share of Earned Personal Income

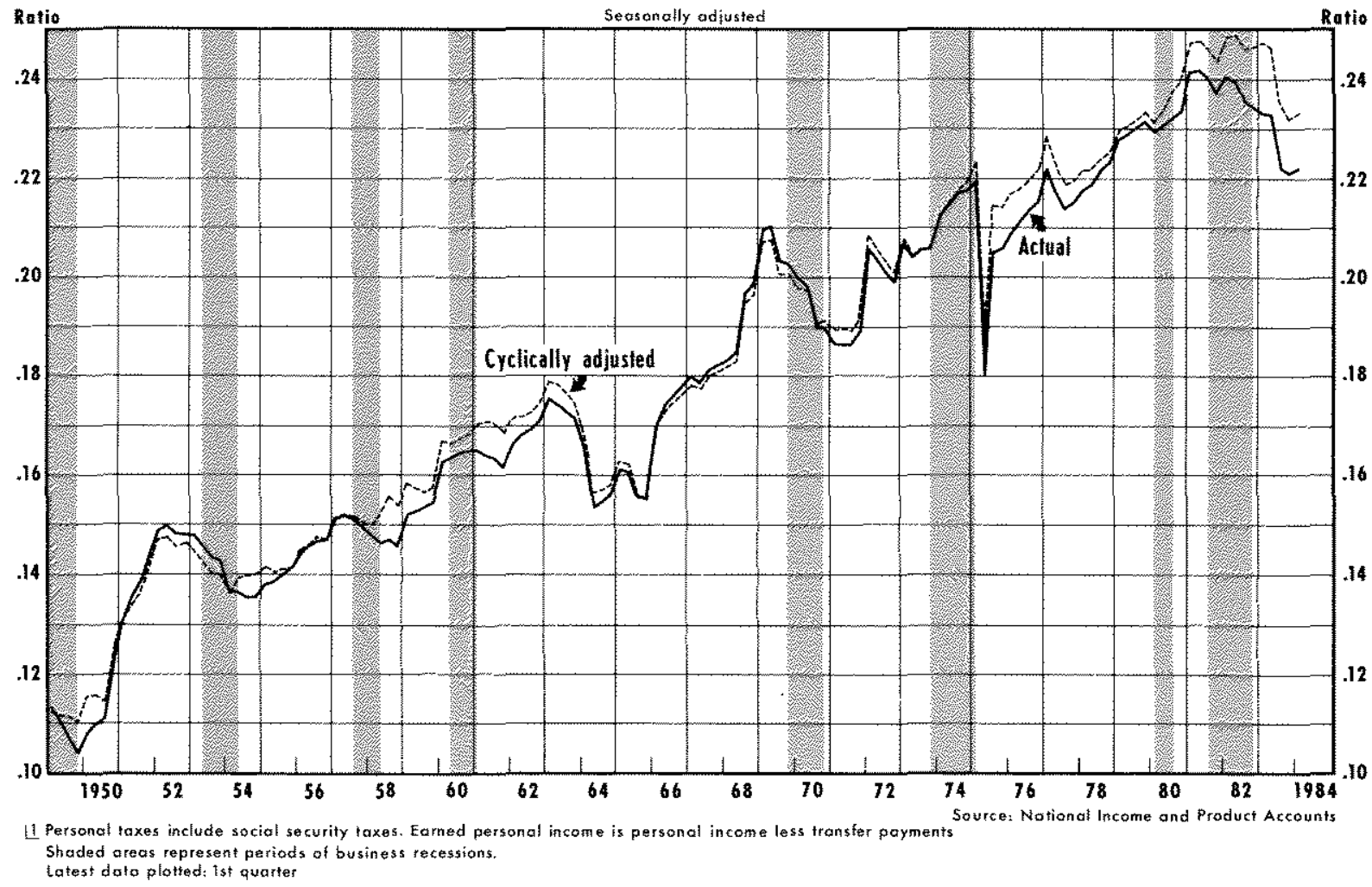

are inadequate for understanding recent deficits. ${ }^{6}$ From 1979 to 1983 , growth in the share of defense spending in GNP accounts for only 1.4 percentage points of a 4.8 percentage-point rise in the deficit as a percent of GNP (from 0.7 percent to 5.5 percent). Other expenditures, in particular transfer payments, account for a considerably larger part of the rise.

The tax cut argument is simply wrong. Personal tax rates generally have risen since the passage of the 1981 tax cut, a "cut" that evidently was a poor substitute for indexing (which begins in 1985). Confusion arises because, while tax rates and taxes obviously were cut from levels that they would otherwise have attained, actual tax rates tended to rise from 1980 to 1984. The cut in personal marginal tax rates was largely offset by inflation-induced "bracket creep" and social security tax hikes:

Business tax cuts, provided primarily through

"See "How to Cut the Deficit" (1984), p. 50, for example.

${ }^{7}$ See Tatom (1981), McKenzje (1982) and Meyer (1983), for example. accelerated depreciation (the Accelerated Cost Recov" ery System) substantially reduced effective tax rates on income from new investments, but had only a minor impact on average tax rates or on the real tax burden on business income from 1980 to $1983 .{ }^{*}$ The lion's share of the observed decline in corporate income taxes as a share of GNP has been related to the business cycle. Lower tax rates on corporate income and accelerated depreciation have been largely offset by new indirect business taxes. Moreover, the taxation of capital, which arises from the use of historical costs in calculating depreciation in the face of inflation-induced boosts in replacement costs, has continued to increase.

Charts 1-3 show clearly that recent budget developments are largely related to the business cycle. During the shaded recession periods, expenditures (especially transfer programs! typically rise and receipts generally fall relative to GNP. Indeed, with the exception of the 1953-54 recession, when expenditures fell relative to GNP as a result of a sharp decline in national defense

\footnotetext{
${ }^{8}$ See Hutten and Robertson (1982) and Meyer.
} 
expenditures, this pattern has been observed in each postwar recession. The greater extent of the recent recession has amplified the cyclical swing in the deficit.

A further example of the effect of the cycle on the federal budget is given in chart 4 , where a measure of the average tax rate on "earned" personal income is given. Transfer payments are excluded from personal income in the chart, because they are not subject to federal taxes; social security contributions are added to federal personal income taxes, because they are considered to be as direct and personal as income taxes. $A$ cyclically adjusted average tax rate measure also is shown.

The rates in chart 4 provide little indication of the so-called tax cut. The actual rate rose from 22.9 percent in 1979 to 23.1 percent in 1980 , then fell slightly to 22.7 percent in 1983. There is some indication of a decline after mid-1982, but the average level for 1983 was virtually unchanged from its 1979 and 1980 levels.

On a cyclically adjusted basis, the evidence that taxes were cut is even weaker. On this basis, the average tax rate rose from 23.1 percent in 1979 to 23.5 percent in 1980 and reached 24.0 percent in 1983 . While the tax rate declined somewhat in 1983 from its 1982 level, it was still above its 1980 level, the yeal" before the "tax cut" begar.

The 1.3 percentage-point difference between the actual and the cyclically adjusted average tax rates represents a $\$ 30.4$ billion shortfall in federal receipts based on the level of income in 1983. Moreover, such income would have been substantially higher if the unemployment rate had averaged 5 percent in 1983 . instead of the actual 9.6 percent ate. Each percentage point of unemployment is associated with about a 2 to $2: / 2$ percentage-point loss in real and nominal GNP and a $2^{1 / 4}$ to $2^{3 / 4}$ percentage-point decline in personal in-

\footnotetext{
${ }^{9}$ The cyclical impact on the tax rate is found from the coefficient on unemployment in a regression model of the tax rate. The equation regresses the quarterly change in the actual tax rate on: changes in the unemployment rate lagged one quarter, the intlation rate (GNP deflator), a time trend, dummy variables to: the 1964 tax cut (1 in the first and second quarters of 1964) and the 1975 tax rebale (1 in the second quarter of 1975 and minus 1 in the third quarter of 1975 ) and a constant, for the period //1950 to W/1983. When the equation is estmated to $1 / 1 / 1981$ and then simulated to IV/T983, it is stable and reveals no significant errors. The cyclically adjusted measure "adds back" the dectine in the tax rate due to the excess of uremployment over a fultemployment unemployment rate of about 5 percent in recent years. The cyclical effect associates a pefcentage-point increase in the unemployment rate with a 0.25 percentage-point reduction in the average tax rate.
}

come less transfer payments. ${ }^{10}$ 'Thus, the loss in personal tax receipts alone in 1983 was about $\$ 72$ billion, a substantial share of the observed budget deficit.

Chart 5 shows the deficit as a percent of GNP and the high-employment deficit as a percent of highemployment GNP." "Typically, the high-employment deficit as a share of high-employment GNP has ranged between plus or minus 2 percent. ${ }^{12}$ While actual deficits have risen substantially as a share of GNP since mid-1981, deficits measuned on a high-employment basis have remained within that range ${ }^{13}$ For example, using fiscal year periods lending in the third quarter of each year), the 1.6 percent high-employment deficit registered in 1983 was equaled or exceeded in 1967 and 1968 (1.8 percent and 1.6 percent, respectively). ${ }^{14}$

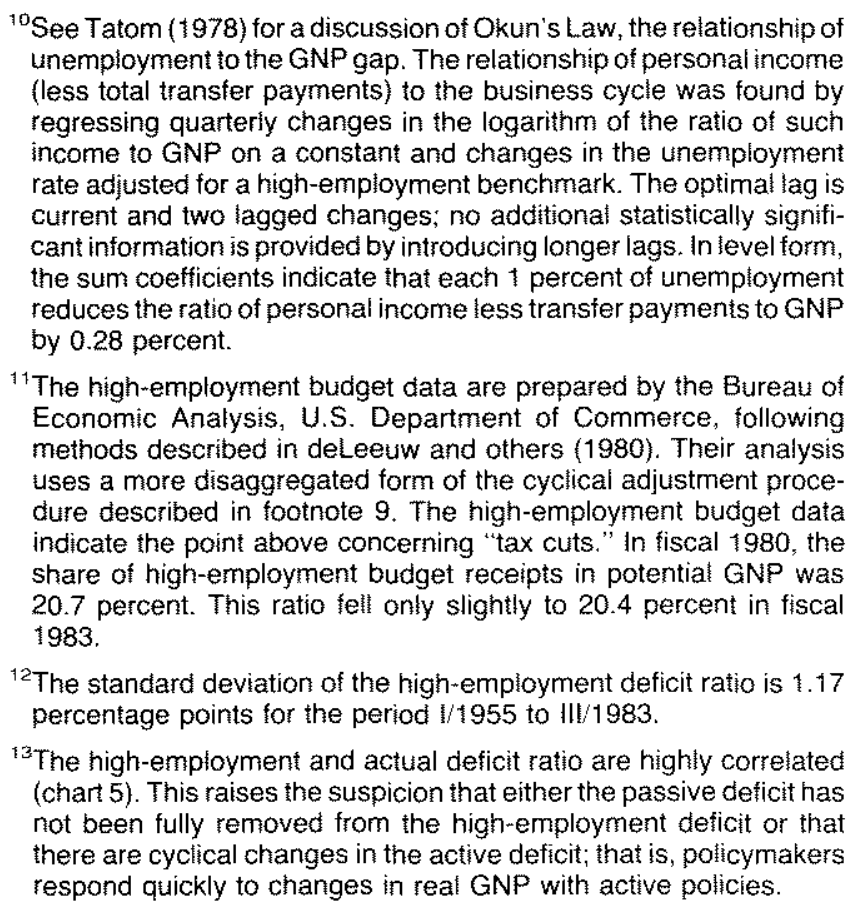

These cyclical movements in the high-employment deftcit ratio were verified by regressing its changes on changes in the unemployment rate, using quarterly data from $1 / 1955$ to ll//1983; $\left(d_{t} \ldots\right.$ $\left.d_{i}\right)=-0.012+0.417\left(U_{1}-N_{t}-N_{t \ldots 1}\right)$, where $d$ is the highemployment deficit ratio (deficits measured positively), and UN is the unemployment rate. The t-statistics are -0.2 and 3.07 for the constant and slope, respectively. Lags on the change in unemployment are not significant. A firstorder autocorrelation correction is used. The unemployment rate (roughly the excess of the unemployment rate above 5 percent in fiscal 1983) coefficient indicates that an extra 5.1 percent unemployment rate raises the measured highemployment deficit ratio by 2.1 percent, somewhat more than the 1.6 percent ratio observed in fiscal 1983. Thus, it appears that the "true" defict ratio for 1983 would be near zero but slightly in surplus.

${ }^{14}$ These earlier peaks in the high-employment (and actual) deficit ratio were of great concern to analysts at the time; in particular, they led to the proposal of a temporary income tax surcharge in January 1967 and its passage in mid-1968. 
Chart 5

Deficits as a Share of GNP

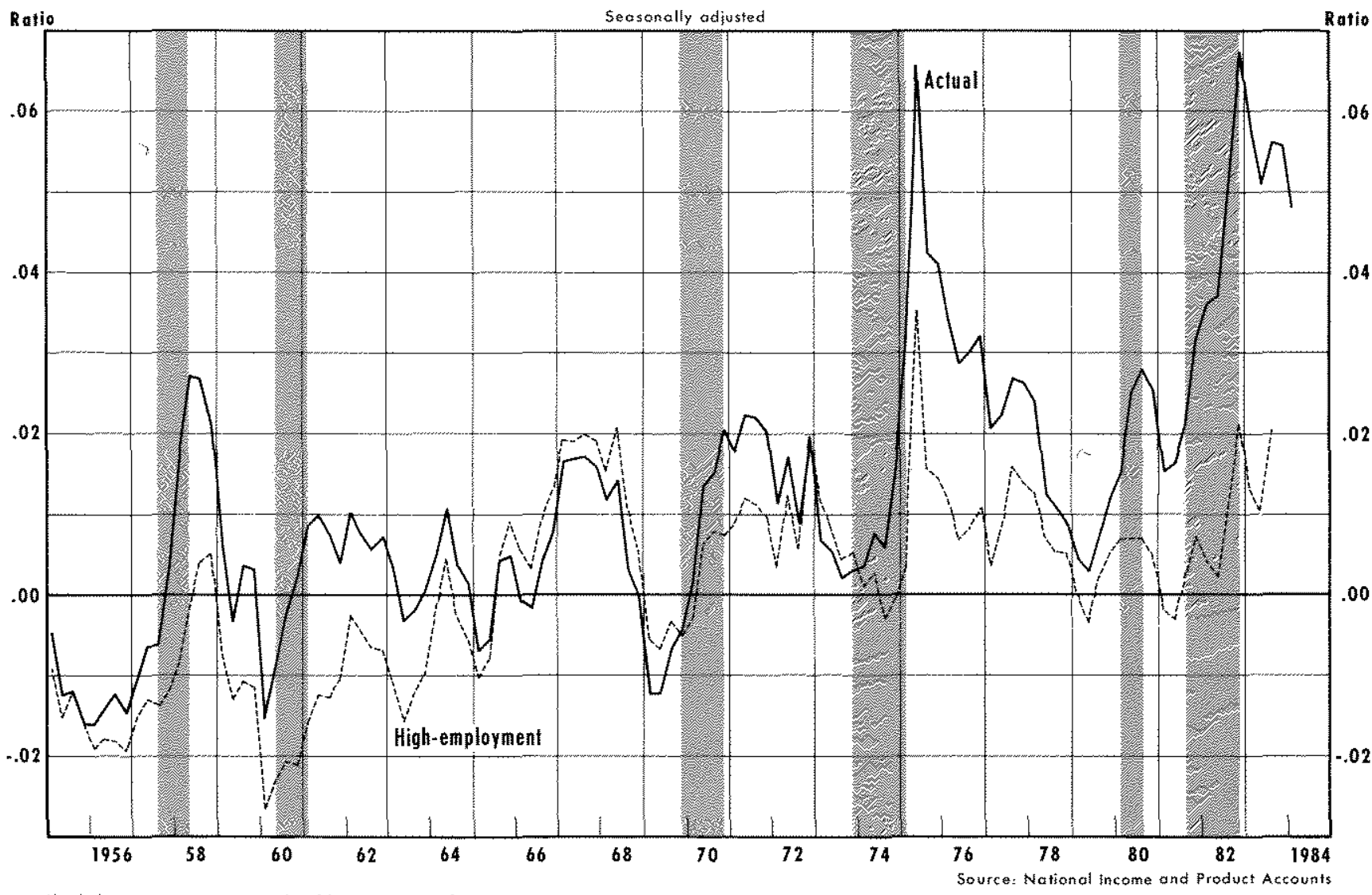

Shoded arens represert periods of business recessions.

tatest data plotted: High-emplaymentuhth quarter; Actuot-last quorier

\section{THE DEFICIT OUTLOOK: FROM PASSIVITO ACTIVE DEFICITS?}

While recent budget deficits appear to have been largely the result of the 1980 and $1981-82$ recessions, projections of future expenditures, receipts and deficits show a different picture. Such projections are shown in table 1 , with earlier actual data for comparison purposes.

The first column in table 1 shows the estimated deficit for fiscal years 1983 to 1989 , based on the assumptions used in the preparation of the fiscal 1985 budget for the economy on a "current services" basis." The current services budget measures assume that all federal programs and activities in the future remain the same as those adopted for the 1984 fiscal year lending

${ }^{15}$ See Council of Economic Advisers (1984), p. 36. in September 1984 and that there are no policy changes in such programs. ${ }^{16}$ They also incorporate assumptions about future spending, real GNP growth, inflation, interest rates and unemployment.

The projected total deficits remain substantial through 1989, providing support for recent concerns about "large" deficits. Note, however, that relative to the size of the economy of GNP, the actual deficit declines after 1983 .

The table also provides a breakdown of the deficit into "cyclical" and "structural" components. This distinction is similar" to the high-employment vs. actual deficit categories used previously. In this instance, however, the cyclical deficit arises from the departure of real GNP from its 1969-to-1981 trend, rather than

${ }^{16}$ For a detailed discussion, see Office of Management and Budget (1984), pp. A-1 to A-38. 


\section{Table 1}

\section{The Cyclical and Structural Components of the Deficit: 1980-89 (dollar amounts in billions)}

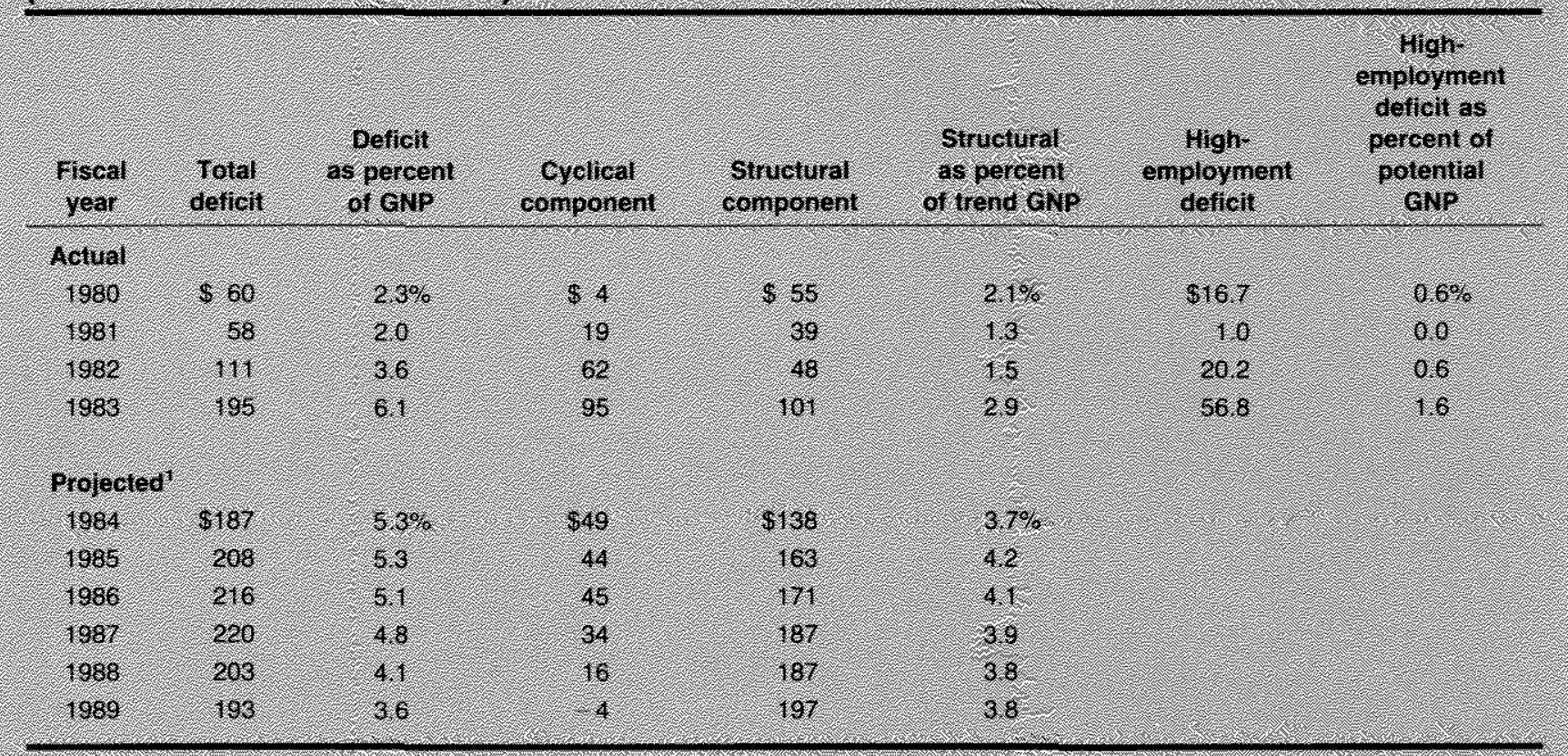

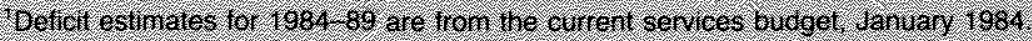

from a high-employment level. The structural deficit is the level that would exist if real GNP were at its trend level; the smaller high-employment deficit measures the deficit that would exist were real GNP at a highemployment level.

While the total deficit declines relative to GNP in the table, the structural deficit balloons up relative to GNP until 1985, then remains quite high as real GNP approaches trend. These estimates show an unprecedented rise in the structural deficit and record levels persisting through the decade.

There are a number of reasons for viewing such conclusions with extreme caution. First, estimates of the structural deficit tend to be raised by the use of trend GNP, since it is somewhat below the path of high-employment GNP. The table also includes highemployment measures of the deficit for 1980 to 1983 , for comparison purposes, ${ }^{17}$ The trend-based estimates of the structural deficit in 1980-83 average about 1.3 percentage points higher than structural deficits that

\footnotetext{
${ }^{17}$ High-employment budget measures exist only through the third quarter of 1983 , following the methods described by deLeeuw and others. Beginning in December 1983, the Bureau of Economic
}

are measured on a high-employment basis. ${ }^{18}$ The size of projected structural deficits in the current budget estimates are likely to be similarly overstated; thus, the projections for 1984 to 1989 do not represent a major break from the record shown in chart $5 .^{19}$ Adjusted for

Analysis switched to a new measure called a "cyclically adjusted" budget. It is not comparable with the earlier series since the benchmark level of GNP is an interpolation of "middle-expansion" phases of the business cycle, at which points unemployment rates have different structural/cyclical components. See deleeuw and Hollo. way (1983). This measure also is not comparable to the trend-based GNP measure anatyzed by the Council of Economic Advisers (1984) and used in table 1.

${ }^{18}$ The budget data in table 1 are for the unitied budget, while the high-employment measures are on an NIA basis. For a discussion of the differences, see Pechman (1983), op. 17-18. The principal difference is that the unified budget is measured on a cash basis, when outlays or receipts are actualizy made, while the NIA budget is measured on an accrual basis; that is, receipts are measured by an increase in tax liability, whether paid or not, and expenditures are measured by purchases, whether cash outlays have been made or not

${ }^{19} \mathrm{Barro}(1984)$ arrives at the same conclusion. He develops a model that explains deficits in terms of expected inflation rates, the business cycle and temporary changes in government spending. His estimates for the period since 1920 indicate that $1982-83$ deficits and projections for 1984 are consistent with the previous structure and do not indicate that there has been a shift in fiscal policy toward higher deficits. 
this difference, the projected 1988-89 deficits are slightly more than twice the standard deviation of the high-employment deficit ratio from 1955 to 1983, instead of over three times as large.

Also, the deficits in table 1 are current services estimates. Currently proposed Administration policies would reduce the structural deficit shown for 1989 to about 2.3 percent of actual of, roughly, trend GNP, instead of the 3.8 percent shown in the table ${ }^{20}$

Third, if actual economic conditions differ from the economic assumptions used for the projections, future deficits could be higher or lower than indicated. Some analysts have been critical of a decline in interest rates assumed in making the projection. If interest rates are higher than projected from 1984 to 1989, the actual and structural deficits would be larger. ${ }^{21}$ Others have criticized the projected rate of economic growth as too low; a higher growth rate would lower the actual and projected deficit. ${ }^{22}$

Economic assumptions are extremely important to deficit projections. Carlson (1983) demonstrates, for example, that changes in assumptions about economic conditions for fiscal 1986 , between projections made in March 1981 and projections made in January 1983, accounted for most of a nearly tenfold rise in the projected deficit from $\$ 21.0$ billion to $\$ 203.1$ billion. Policy changes between the two projections reduced

\footnotetext{
20 The Administration proposals would do this by reducing a projected 23.0 percent share of outlays in GNP by 0.9 percentage points and raising the 19.4 percent share of receipts by 0.4 percentage points, reducing the projected actual deficit to 2.3 percent. The proposed spending reductions include paring back 0.2 percentage points of the rise in the share of national defense outlays. The rest of the reduction is in net interest $(0.2$ percent), social security and Medicaid (0.1 percent) and other transier payments and non defense expenditures.

${ }^{21}$ This criticism is subject to a fundamental qualification, however. The assumed lower interest rates from 1984 to 1989 are largely prem. ised upon a decline in infation. If recent or higher interest rates are assumed because inflation is assumed to be the same or higher, then the impact of the higher interest rates on the interest component of outlays and the deficit would be more than offset by the positive effect of inflation on receipts relative to expenditures.

${ }^{22}$ Foremost among the critics has been the Congressional Budget Office (1984). Its principal departures from the assumptions used by the Administration are that: interest rates decline much less for $1984-89$ and real GNP growth is slower in 1986-89. As a result, the deficit generalyy rises in the CBO projections, from $\$ 186$ billion in 1984 to $\$ 248$ billion in 1989 .

The $\mathrm{CBO}$ does not discuss the structural deficit issue. Nonetheless, under its more pessimistic assumptions the deficit declines as a share of GNP from 6 . 1 percent in 1983 to 5.2 percent in 1984 , to about 5 percent in 1985-87 and to 4.8 percent and 4.6 percent in 1988 and 1989, respectively (p. 2). Moreover, its discussion of the consequences of "large deficits" indicates that financing of such deficits will take a substantially smaller share of gross and net
} private domestic savings in $1984-85$ than in 1983 (o. 19), the projected deficit by about $\$ 39$ billion, but down. ward revisions in the projected levels of prices and real GNP for 1986 raised it by $\$ 221$ billion.

Even departures from near-term assumptions can have relatively large effects on projected deficits. For example, at the end of July 1983, the Offlce of Management and Budget (1983) estimated that the unified budget deficit for fiscal 1983, which ended two months later, would show a deficit of $\$ 209.8$ billion. "Two months later, the actual deficit ended up at $\$ 195.4$ billion, primarily because outlays were about $\$ 13$ billion lower than estimated two months earlier, when most of the fiscal year had been completed.

\section{THE CONSEQUENCES OF LARGE DEFICITS}

Conventional economic theory suggests that rising deficits mav tend to raise prices, output and interest rates, while depressing capital formation. Obtaining empirical support for all but the last of these hypoth" eses has proved quite difficult, however. ${ }^{23}$

In 1981, concern over rising deficits associated with the Economic Recovery Tax Act of 1981 focused on the anticipation that increasing deficits would overheat the economy and raise inflation, just as inflation measures began to plummet and the economy entered the worst recession since the 1930s. ${ }^{24}$ Since then, in creased attention has been focused on the effect of deficits on interest rates and capital formation during a period in which, until recently, interest rates were declining and capital spending was unusually high relative to GNP. ${ }^{25}$ In part, finding evidence on the consaquences of deficit increases becomes difficult be-

\footnotetext{
${ }^{23}$ Carlson (1982) presents evidence supporting the view that deficits crowd-out private sector capital formation.

${ }^{2 *}$ Heir (1981) explains the stortcomings of the hypothesized link between deficits and inflation. Essentially, as he notes, the fundamental linkage in such a hypothesis is the extent to which deficits are monetized; that is, the share of the deficit financed by the Federal Reserve through money creation, primarily open market purchases of government securities. There has been no such linkage since at leasi 1974. For a contrasting view, see Hamburger and Zwick (1981, 1982). McMillin and Beard (1982) have pointed to some shortcomings of the Hamburger-Zwick analysis

${ }^{25}$ Curiously, analyses of proposals to deal with large future deficits by raising taxes of cutting federal spending growth emplasize the effects of such programs in avoiding rising interest rates that purportedly could choke off the current expansion. Higher interest rates resulting from future deficits, to the extent they would occur, are already part of the existing structure of interest rates. Such analyses typically ignore conventional thinking, which emphasizes that such fiscal programs directly retard spending and, hence, expansions, despite any effect of lower interest rates. Kopcke (1983), for exam. ple, has emphasized this point.
} 
cause of a failure to account for the active/passive defcit distinction. This problem is most apparent when one looks at the investigation of the deficit-interest rate link.

The actual pattern of deficits and interest ates over the past four years runs counter to the higher-deficit, higher-interest rate hypothesis. Interest rates skyrocketed from IIV/1979 to III/1981; long-term Treasury security yields, for example, rose from about 9 percent to 14 percent. During the same period, the highemployment deficit for the most recent four quarters fell from about $\$ 2$ billion to $\$ 1$ billion, and the actual deficit rose from about $\$ 14$ billion to $\$ 56$ billion. Over the next two years (III/1981 to III/1983), long-term Treasury security yields fell from 14 percent to 11.6 percent. Yet, in the latter period, the actual deficit ballooned up to $\$ 186$ billion and the high-employment deficit rose from near zero to about $\$ 57$ billion. ${ }^{2}$

A principal difficulty in interpreting these movements in interest rates and deficits is the failure to account for the active/passive deficit distinction. In the past, deficits have been in large part passive, as chart 5 indicates. Thus, it is not suprising that, during and following periods of recession, deficits were rising or "high," and interest rates were falling or remained "low." The dominance of this negative cyclical rela" tionship between passive deficits and interest rates interferes substantially with empirical investigations of the impact of deficits on interest rates. An example of this confusion is detailed in the insert on pages 16 and 17 .

The second problem with testing the interest ratedeficit hypothesis is that the U.S, economy has had only limited peacetime experience with either large or variable active deficits, measured relative to GNP. As chart 5 indicates, deficits or surpluses rarely have exceeded 2 percent of GNP on a high-employment basis.

Thus, should future federal structural deficits be larger than they were in the earlier postwar experience. past empirical evidence would provide little guidance concerning the potential adverse effects on inflation and interest rate levels. Although past evidence suggests there are none, the economy has had no peacetime experience with large, persistent structumal defi-

\footnotetext{
${ }^{26}$ Another such striking paralle occurred in fiscal 1975 (measured here as IV/1974 to Iil/1975) when the deficit ballooned to $\$ 58.4$ billion from $\$ 6.9$ billion in fiscal 1974 . This set a postwar record, exceeding even the 1943 budget deficit of $\$ 54.9$ billion. As a share of GNP. the 3.8 percent 1975 deficit also set a postwar record, not exceeded until fiscal 1982 . Nonetheless, 3 -month Treasury bill rates fell trom about 9 percent in the fall of 1974 to about 5.5 percent at the end of 1975. See Carlson (1976) and Lang (1977) for a discussion of this episode.
}

cits, as some analysts have suggested will occur from 1983 to 1989. Thus, the past may offer little relevant evidence for assessing the future effects of deficits. Ot course, financial market participants have been wamed of the potential magnitude of future deficits and, to the extent such deficits could be expected to raise interest rates, such effects already should have been incorporated into the structure of rates. Interestingly enough, however, interest rates have generally fallen since late 1981, even though it has been only since then that the adverse deficit information began to be discerned and disseminated.

\section{SUMNAR}

In 1982-83, federal deficits surged to triple-digit levels. Moreover, administation and $\mathrm{CBO}$ projections indicate they will remain so, at least through 1989. These deficits have arisen from the unsatisfactory cym clical performance of the U.S. economy. Typically federal expenditures are raised when unemployment is higher and tax receipts are lower. Recessions in 1980 and 1981-82 have left the unemployment rate at unusually high levels since 1980 . Suggestions that either a rise in defense spending or cuts in tax rates have played majot roles in the creation of recent deficits are misleading.

Projections tend to show deficits declining as a share of GNP, but structural deficit projections show a worsening trend in 1984-85 and little improvement in 1986-89. Should the current cyclical deficit be transformed into a structural deficit, it is not clear what consequences such a development would have. There is little evidence supporting the adverse consequences of a sharp increase in the stuctural deficit. The lack of such evidence, however, may arise from the fact that the United States has had no experience with "large" peacetime structural deficits.

\section{TEREPRNCES}

Barro, Robert J. "The Behavior of U.S. Deficits," National Bureau of Economic Research Working Paper No. 1309, March 1984.

. "Comment From An Unreconstructed Ricardian," Journal of Monetary Economics (Augusi 1978), pp. 569-81.

"Are Government Bonds Nel Weatth?" Journal of Polltical Economy (November/December 1974), pp. 1095-117.

Buchanan, J. M., and R. Wagner. Democracy in Deficit (Academic Press, 1977).

Carlson, Keith M. "The Critical Role of Economic Assumptions in the Evaluation of Federal Budget Programs," this Review (October 1983), pp. 5-14.

"The Mix of Monetary and Fiscal Policies: Conventional Wisdom Vs. Empirical Reality," this Review (October 1982), pp. $7-21$. 
"Large Federal Budget Deficits: Perspectives and Prospects," this Review (October 1976), pp. 2-7.

Carlson, Keith M., and Roger W. Spencer. "Crowding Out and its Critics," this Review (December 1975). pp. 2-17.

Cohen, Darrel, and Peter B. Clakk. The Effects of Fiscal Policy on the U.S. Economy, Staff Studies No. 136 (Board of Governors of the Federal Reserve System, Jantuary 1984).

Congressional Budget Office. The Economic Outlook, Congress of the United States (U.S. Govemment Printing Office, February $1984 a)$.

An Analysis of the President's Budgetary Proposals for Fiscal Year 1985, Congress of the United States (GPO, February 1984b).

Council of Economic Advisers. Economic Report of the President (GPO, February 1984).

Greider, Willam. "The Education of David Stockman," The Atlantic Monthly (December 1981 ), pp. 27-54.

Hamburger, Michael J, and Burton Zwick. "Deftcts, Money and fnflation," Journal of Monetary Economics (January 1981), pp. $141-50$

"Deficits, Money and Inflation: Reply, Journal of Mortetary Economics (September 1982), pp. 279-83.

Hein, Scott E. "Deficits and Inflation," this Review (March 1981), pp. $3-10$.

"How to Cut the Deficit." Business Week, Special Report (March 26, 1984), pp. 49-106.

Huten, Charles A, and James W. Robertson. 'Corporate Tax Policy and Economic Growth: An Analysis of the 1981 and 1982 Tax Acts," Urban Institute Discusston Paper (December 1982).

Knoester, Anthonie. "Stagnation and the Inverted Haavelmo Effect: Some international Evidence," De Economist, volume 131 , no. 4 , (1983), pp. 548-84.

Kochin, Levis A. "Are Future Taxes Anticipated by Consumers?" Journal of Money, Credit and Banking (August 1974), pp. 385-94.

Kopcke, Richand W. "Will Big Deficts Spol the Recovery?" in Federal Reserve Bank of Boston, The Economics of Large Government Deficits, Conference Series No. 27 (1983), op. 141-68.
Lang, Fichard $W$. "The 1975-76 Federal Deficits and the Credit Market," this Review (January 1977), pp. 9-16.

deleetw, Frank, and Thomas M. Holloway. "Cyclical Adjustment of the Federal Budget and Federal Debt," Survey of Cument Business (December 1983), pp, 25-40

deleeuw, Frank, and others. "The Highm Employment Budget: New Estimates, 1955 80," Survey of Current Business (November 1980), pp. $13-43$.

Mckenzie, Richard B. "Supplym Side Economics and the Vanishing Tax Cut," Federal Reserve Bank of Atlanta Economic Review (May 1982), pp. 20-24.

McMilin, W. Douglas, and Thomas R. Beard. "Deficits, Money and Inflation: Comment, ${ }^{\text {th }}$ Journal of Monetary Economics (September 1982), pp. $273-77$

Meyer, Stephen A. "Tax Cuts: Reality or llusion," Federal Reserve Bank of Philadelphia Business Revjew (July/August 1983), pp 3-16.

Office of Management and Budget, Budget of the United States Government 1985 (GPO, February 1984).

1983).

Pechman, Joseph A. Federal Tax Policy, 4th ed. (The Brookings Institute, 1983).

Plosser, Charles I., and G. Wiltiam Schwert. "Money Income and Sunspots: Measuring Economic Relationships and the Effects of Differencing," Journal of Monetary Economics (1978), pp. $637-60$.

Tatom, John A. "We Are All Supply-Siders Now!" this Review (May 1981), pp. 18-30, reprinted in Bruce Bartlett and Timothy P. Foth, The Supply-Side Solution (Chatham House Publishers, Inc. 1983), pp. $6-25$.

"Economic Growth and Unemployment: A Reappraisa of the Conventional View, "this Review (October 1978), pp. 16-22

4.S. Department of the Treasury. The Effects of Deficits on Prices of Financial Assets: Theory and Evidence (GPO, March 1984).

\section{Interest Rates and the Deficit: 1955-83}

When the lexel of interest rates is felited to the

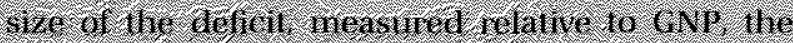
retationship is renirall hegative instead of positive as is orten comiertined. Moreoyer the regative ith

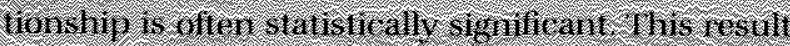
arises hecritse of the cimultaneaus of currence of cyclical defien inertasts and recession triated deremases in inierest attes, espectall, shom tem in. tertst rates:

This pattern cleart energes in an examination or quarted y changes in bolth the 3 -nonth Treasiny bill

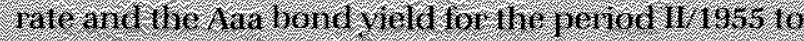

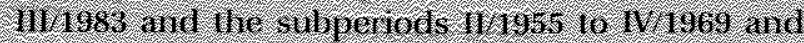
11970 10 111 1983 . These chinges, were regresser on curent and pist eltanges in the cetual federal def: cit-eNI ratio and on cuneil and past changes in the high emploment detcitpontentiat GNP atio Allioigh up to four past quarted, changes were examined, ne lagged valines were statis ireally sighiil. cant in eilhee rase the table shiwh the fequthors for erachinmerest rate, tor each penod for cach def: ent (rNi) ratio,

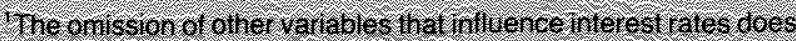

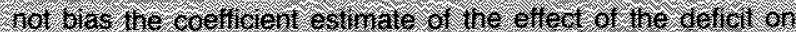

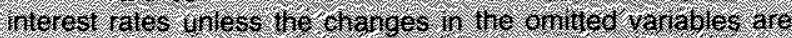

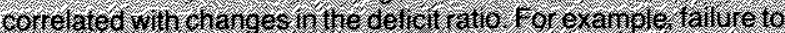

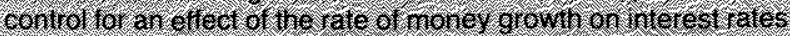
does hor bias he coeficrent esthiales here viness thanges is

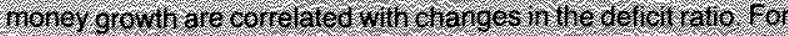

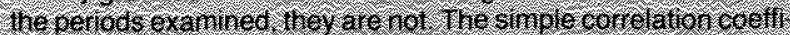
dent for changes in Mr gromth and an the achua deficit ratio is

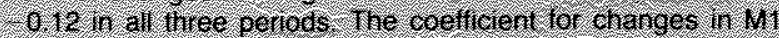

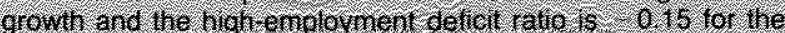

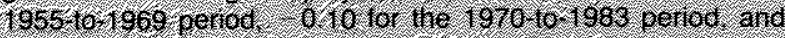

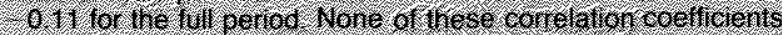
are stanistually ssgniticant at 3.95 potrent conticence level

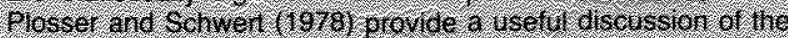

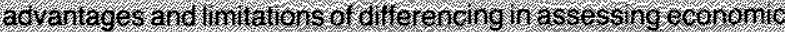
relationships 


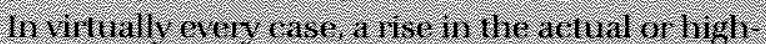

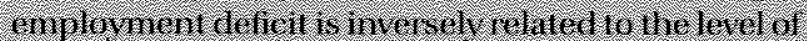

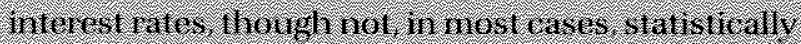

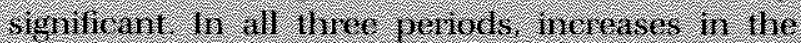

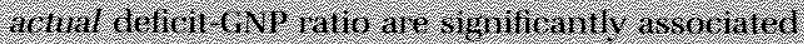

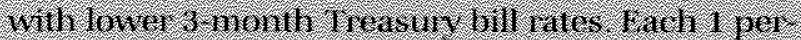

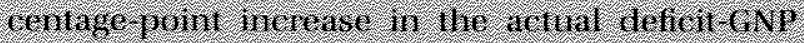

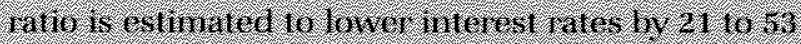

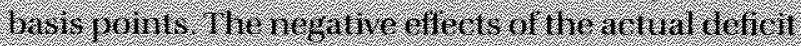

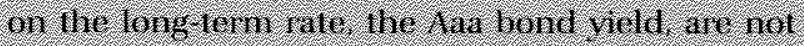

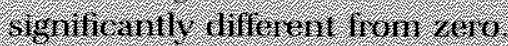

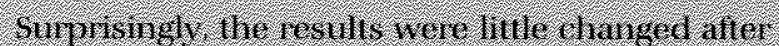

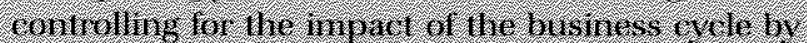

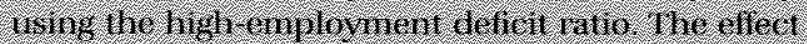

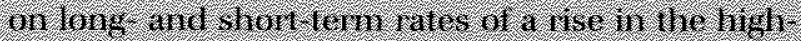

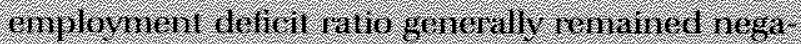

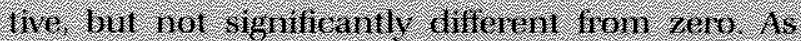

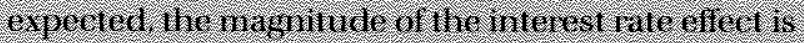

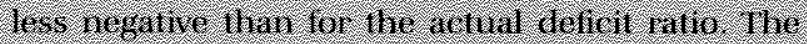

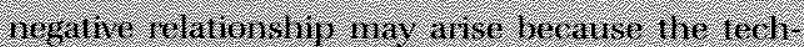

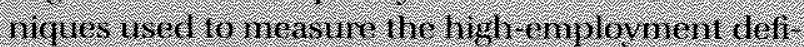

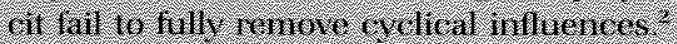

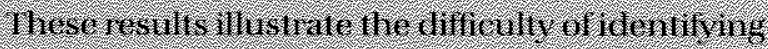

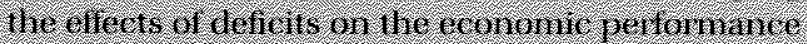

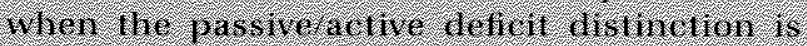

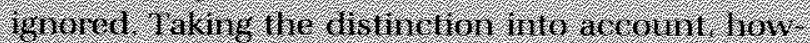

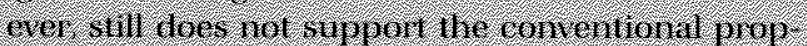

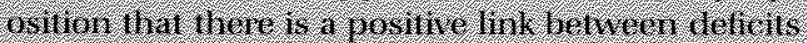
and nilevest rates.

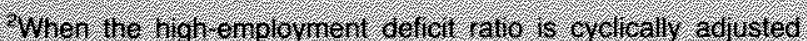

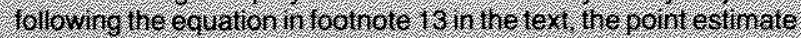

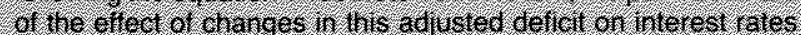

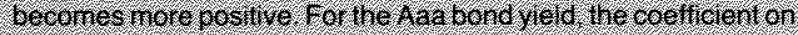

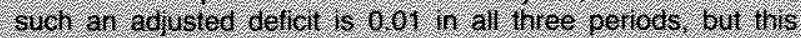
posilve relationithip is not statisticaly sighitcant fhe 1 statistic is

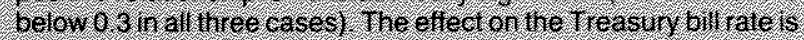

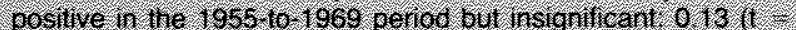

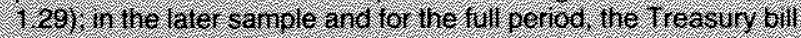

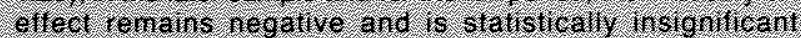
(rstaistics test 1 han 070 in absolute value)

\section{Interest Rates and the Federal Deficit}

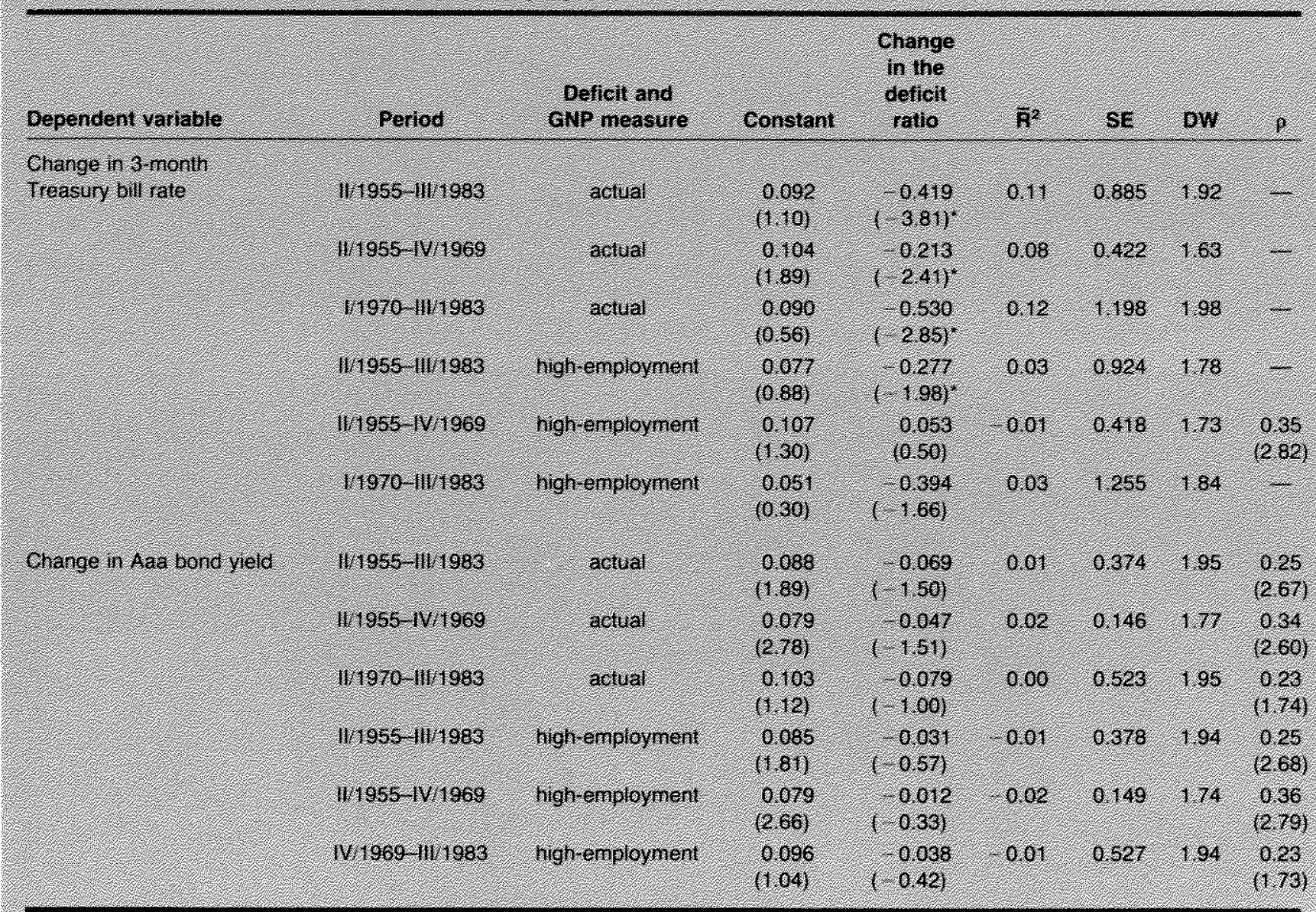

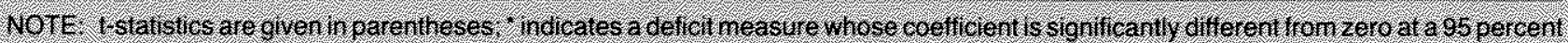
confidence level 